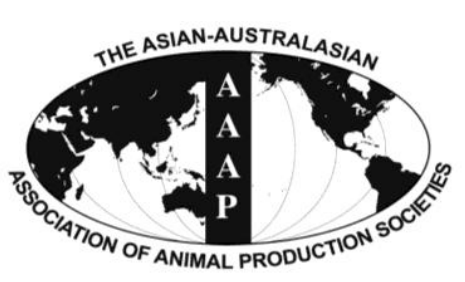

Open Access

Asian Australas. J. Anim. Sci.

Vol. 27, No. 3 : 365-374 March 2014

http://dx.doi.org/10.5713/ajas.2013.13494

www.ajas.info

pISSN 1011-2367 elSSN 1976-5517

\title{
Effects of Dietary Crude Glycerin Supplementation on Nutrient Digestibility, Ruminal Fermentation, Blood Metabolites, and Nitrogen Balance of Goats
}

\author{
P. Chanjula ${ }^{1}$ *, P. Pakdeechanuan ${ }^{2}$, and S. Wattanasit ${ }^{1}$ \\ ${ }^{1}$ Department of Animal Science, Faculty of Natural Resources, \\ Prince of Songkla University, Songkhla 90112, Thailand
}

\begin{abstract}
This experiment was conducted to evaluate the effects of increasing concentrations of crude glycerin (CGLY) in diets on nutrient utilization, ruminal fermentation characteristics, and nitrogen utilization of goats. Four male crossbred (Thai Native $\times$ Anglo Nubian) goats, with an average initial weight of $26 \pm 3.0 \mathrm{~kg}$, were randomly assigned according to a $4 \times 4$ Latin square design with four 21 days consecutive periods. Treatments diets contained 0\%, 5\%, 10\%, and 20\% of dietary DM of CGLY. Based on this experiment, there were no significant differences ( $\mathrm{p}>0.05$ ) among treatment groups regarding DM intake and digestion coefficients of nutrients (DM, OM, $\mathrm{CP}, \mathrm{EE}, \mathrm{NDF}$, and ADF). Likewise, mean serum glucose, BHBA, and PCV concentrations were not affected ( $p>0.05)$ by dietary treatments, whereas serum insulin concentration linearly increased $(\mathrm{L}, \mathrm{p}=0.002)$ with increasing the amount of CGLY supplementation. Ruminal $\mathrm{pH}, \mathrm{NH}_{3}-\mathrm{N}$, and BUN concentration were unchanged by dietary treatments, except for $20 \%$ of CGLY, $\mathrm{NH}_{3}-\mathrm{N}$, and BUN were lower $(\mathrm{p}<0.05)$ than for the diets $10 \%$ of CGLY, while the difference between the diets $0 \%, 5 \%$, and $20 \%$ of CGLY were not significant. The amount of $\mathrm{N}$ absorption and retention were similar among treatments. Based on this study, CGLY levels up to $20 \%$ in total mixed ration could be efficiently utilized for goats and this study elucidates a good approach to exploiting the use of biodiesel production for goat production. (Key Words: Crude Glycerin, Nutrient Digestibility, Ruminal Fermentation, Goat)
\end{abstract}

\section{INTRODUCTION}

Because of the rising costs of energy-rich feedstuffs, alternative feed sources such as glycerin (or glycerol) have become a major focus for the livestock industry. The livestock feeding industry has readily adopted alternative feed ingredients in order to maintain or lower costs of gain. Crude glycerin (CGLY) is the principal co-product of biodiesel production, obtained in the process of transesterification of triacylglycerols of plant oils or animal fats, usually using methanol and a catalyst (sodium methylate) (Thompson and He, 2006). Approximately 7.9

\footnotetext{
* Corresponding Author: Pin Chanjula. Tel: +66-74-558805, Fax: +66-74-558805, E-mail: pin.c@ psu.ac.th

${ }^{2}$ Department of Food Science and Nutrition, Faculty of Science and Technology, Prince of Songkla University, Pattani Campus, Pattani 94000, Thailand.

Submitted Aug. 11, 2013; Accepted Oct. 21, 2013; Revised Nov. 4, 2013
}

$\mathrm{kg}$ of crude glycerin is generated per $100 \mathrm{~L}$ of biodiesel produced (Thompson and He, 2006), or $10 \%$ of the weight of vegetable oil or fat that is used to produce biodiesel becomes glycerin (Dasari et al., 2005). Therefore, the existing biodiesel industry is likely to provide a substantial amount of crude glycerin to be used not only for the production of chemical products, fuel additives, hydrogen, ethanol and etc., but also as an energy source in animal diets (Gunn et al., 2010a). Previous studies concluded that glycerin from biodiesel production was an acceptable source of energy for poultry (Lammers et al., 2008a; Min et al., 2010) and swine (Lammers et al., 2008b; Schieck et al., 2010).

In ruminants, different quantities of glycerin are either converted to volatile fatty acids, particularly propionate and butyrate at the expense of acetate, or are directly absorbed from the digestive system and will act as a precursor for gluconeogenesis in the liver (Rémond et al., 1993; Krehbiel, 
2008). Researchers reported that $35 \%$ to $69 \%$ of the crude glycerol administered was used to produce propionate (Rémond et al., 1993). If crude glycerol increased propionate concentration, an increased gain-to-feed (GF) would be expected (Hungate, 1966). Feeding glycerin may also improve feed digestibility and increase the microbial protein production in the rumen of cattle in a dosedependent manner (Wang et al., 2009). The potential value of crude glycerin as a major component of the diet has been reported in beef cattle (Pyatt et al., 2007; Mach et al., 2009; Parsons et al., 2009) and dairy cows (Donkin et al., 2009; Carvalho et al., 2011), and inclusions of $10 \%$ to $20 \%$ in diet DM have been used without negatively affecting to lamb performance (Gunn et al., 2010a, 2010b). However, there is little information available regarding the effects of this byproduct on the intake, digestibility, ruminal characteristics, and nitrogen balance of goats fed moderate to high amounts of glycerol, Therefore this study aimed to evaluate the effects of CGLY on feed intake, digestibility, ruminal fermentation characteristics, blood metabolites, and nitrogen balance while establishing an optimal feeding amount in goat fed diets containing corn grain.

\section{MATERIALS AND METHODS}

All procedures involving animals were approved by the Ethical Principles for the Use of Animals for Scientific Purposes of the National Research Council of Thailand (NRCT) for the metabolism study and finishing study.

\section{Animals, treatments, and experimental design}

Four male crossbred (Thai Native $\times$ Anglo Nubian) goats, about 18 months old and $26 \pm 3.0 \mathrm{~kg}$ body weight, were randomly assigned according to a $4 \times 4$ Latin square design to investigate the effects of crude glycerin (CGLY) on feed intake, digestibility, ruminal fermentation, blood metabolites, and nitrogen balance. The dietary treatments consisted of $0 \%, 5 \%, 10 \%$, and $20 \%$ of CGLY (DM basis) replacing corn grain that were formulated to be isonitrogenous at $15 \%$ of $\mathrm{CP}$ and isocaloric at $2.63 \mathrm{Mcal} / \mathrm{kg}$ DM (on a ME basis) and to meet or exceed the NRC (1981) requirements of growing goats. The CGLY was produced in a palm-diesel facility (New Biodiesel, Surat Thani Province, Thailand) and contained $87.61 \%$ of glycerin, $8.07 \%$ of water, $1.24 \%$ of sodium, and $0.64 \%$ of methanol. Palmderived glycerin from single batch was added to the total mixed ration (TMR) as liquid. The ingredients and determined chemical composition of the components of each diet are presented in Table 1.

All goats were kept individually in ventilated pens under well-ventilated sheds where water and mineral salt were available at all times. The experiment was conducted for 4 periods, and each period lasted for 21 days. During the first $14 \mathrm{~d}$ of each period, all animals were fed the respective diets for ad libitum intake, whereas during the last $7 \mathrm{~d}$, the animals were moved to metabolism crates for total collection during the time goats were restricted to $90 \%$ of the previous voluntary feed intake to ensure total feed intake. Feeds were provided twice in two equal portions daily at 0800 and 1600 h. For determination of daily DMI, refusals were collected and weighed daily before feeding. Feed samples obtained each time were oven dried at $60^{\circ} \mathrm{C}$ for $72 \mathrm{~h}$ and ground to pass through a 1-mm sieve, and composited by period on an equal weight basis for further analysis. Goats were individually weighed before the morning feeding at the beginning and end of each experimental period.

\section{Data collection and sampling procedures}

Feeds, urine, and fecal samples were taken from the total collection of each individual goat in each treatment during the last 7 days of each period at the morning and afternoon feeding. Composited samples were dried at $60^{\circ} \mathrm{C}$, ground (1-mm screen using Cyclotech Mill, Tecator), and analyzed for DM, ether extract, ash, CP content (AOAC, 1995), and NDF and ADF (Goering and Van Soest, 1970). NDF was analyzed without $\alpha$-amylase, and the value of NDF and ADF were expressed inclusive of residual ash. Non-fibrous carbohydrate ( $\%$ in the DM) was calculated as (Mertens, 1997): 100- (CP+NDF+ether extract+ash).

At the end of each period, ruminal fluid was collected from all goats by using a stomach tube at 0 and 4 h-post feeding during the digestibility trial. This was strained through 4 layers of cheese cloth and $\mathrm{pH}$ measured immediately using a $\mathrm{pH}$ meter (HANNA instruminalts $\mathrm{HI}$ 98153 microcomputer $\mathrm{pH}$ meter, Singapore) fitted with a combined electrode. The ruminal fluid was then acidified with $3 \mathrm{~mL}$ of $1 \mathrm{M} \mathrm{H}_{2} \mathrm{SO}_{4}$ added to $30 \mathrm{~mL}$ of ruminal fluid. The mixture was centrifuged at $16,000 \times g$ for $15 \mathrm{~min}$, and the supernatant was stored at $-20^{\circ} \mathrm{C}$ before $\mathrm{NH}_{3}-\mathrm{N}$ analysis by using the micro-Kjeldahl methods (AOAC, 1995) and VFA analysis by using HPLC (Samuel et al., 1997). Blood samples (about $10 \mathrm{~mL}$ ) were collected from a jugular vein (at the same time as ruminal fluid sampling) into tubes containing $12 \mathrm{mg}$ of EDTA, and plasma was separated by centrifugation at $2,500 \times g$ for $15 \mathrm{~min}$ at $5^{\circ} \mathrm{C}$ and stored at $-20^{\circ} \mathrm{C}$ until analysis of plasma urea $\mathrm{N}$ according to the method of Crocker (1967). On the last day of each period, the goats were removed from the metabolism crates and transported to their individual pens for the adaptation of the next diet.

\section{Laboratory analyses}

Feed, feed refusals and feces were analyzed in duplicate for DM, ash, CF, ether extract and Kjeldahl N using AOAC 
Table 1. Ingredients and chemical composition of goat diets containing increasing amounts of crude glycerin (\% DM basis)

\begin{tabular}{|c|c|c|c|c|}
\hline \multirow{2}{*}{ Item } & \multicolumn{4}{|c|}{ Dietary crude glycerin (\% of dietary DM) } \\
\hline & 0 & 5 & 10 & 20 \\
\hline \multicolumn{5}{|l|}{ Ingredients (\%) } \\
\hline Crude glycerin ${ }^{1}$ (CGLY) & 0.00 & 5.00 & 10.00 & 20.00 \\
\hline Ground corn (GC) & 46.00 & 41.00 & 35.45 & 24.50 \\
\hline Soybean meal, SBM (44\% CP) & 16.20 & 16.10 & 16.55 & 18.21 \\
\hline Fish meal $(55 \% \mathrm{CP})$ & 2.00 & 2.00 & 2.00 & 2.00 \\
\hline Leucaena leave meal (LLM) & 6.00 & 6.00 & 6.00 & 5.65 \\
\hline Plicatulum hay $(\mathrm{PH})$ & 25.00 & 25.00 & 25.00 & 25.00 \\
\hline Molasses & 3.00 & 3.00 & 3.00 & 2.54 \\
\hline Salt & 0.20 & 0.20 & 0.20 & 0.20 \\
\hline Dicalcium phosphate & 0.30 & 0.30 & 0.30 & 0.30 \\
\hline Urea & 0.30 & 0.40 & 0.50 & 0.60 \\
\hline Mineral and vitamin $\operatorname{mix}^{2}$ & 1.00 & 1.00 & 1.00 & 1.00 \\
\hline \multicolumn{5}{|c|}{ Analyzed nutrient composition ${ }^{3}(\%$ of DM) } \\
\hline $\mathrm{DM}^{4}$ & 86.94 & 86.77 & 85.85 & 85.99 \\
\hline Ash & 6.48 & 6.21 & 6.41 & 6.53 \\
\hline $\mathrm{OM}$ & 93.52 & 93.79 & 93.59 & 93.47 \\
\hline $\mathrm{CP}$ & 15.44 & 15.32 & 15.31 & 15.45 \\
\hline $\mathrm{EE}$ & 2.62 & 2.12 & 2.25 & 2.15 \\
\hline NFC & 31.39 & 34.05 & 37.79 & 36.79 \\
\hline NDF & 44.07 & 42.33 & 38.24 & 39.08 \\
\hline $\mathrm{ADF}$ & 19.44 & 19.97 & 20.00 & 19.07 \\
\hline $\mathrm{Ca}$ & 1.12 & 1.11 & 1.15 & 1.13 \\
\hline $\mathrm{P}$ & 0.38 & 0.35 & 0.36 & 0.34 \\
\hline $\operatorname{ME}(\mathrm{Mcal} / \mathrm{kg} \mathrm{DM})^{5}$ & 2.63 & 2.63 & 2.63 & 2.63 \\
\hline
\end{tabular}

${ }^{1}$ Contained $87.61 \%$ of glycerin, $8.07 \%$ of water, $1.24 \%$ of sodium, and $0.64 \%$ of methanol (Colorless, odorless, viscous liquid obtained from Biodiesel Producers, New Biodiesel, Surat Thani Province, Thailand.).

${ }^{2}$ Minerals and vitamins (each kg contains): Vitamin A 10,000,000 IU; Vitamin E 70,000 IU; Vitamin D 1,600,000 IU; Fe 50 g; Zn 40 g; Mn 40 g; Co 0.1 $\mathrm{g} ; \mathrm{Cu} 10 \mathrm{~g} ; \mathrm{Se} 0.1 \mathrm{~g} ; \mathrm{I} 0.5 \mathrm{~g}$.

${ }^{3}$ Based on analysis of composite feed sample.

${ }^{4} \mathrm{DM}=$ Dry matter; $\mathrm{OM}=$ Organic matter; $\mathrm{CP}=$ Crude protein; $\mathrm{EE}=$ Ether extract; $\mathrm{NSC}=$ Non-structural carbohydrate; $\mathrm{NDF}=\mathrm{Neutral}$ detergent fiber; $\mathrm{ADF}=$ Acid detergent fiber; $\mathrm{ADL}=$ Acid detergent lignin.

${ }^{5}$ Calculated with an estimated ME for glycerol of $3.47 \mathrm{Mcal} / \mathrm{kg}$ of DM (Mach et al., 2009).

(1995) procedures. Neutral detergent fiber (NDF), acid detergent fiber (ADF) and acid detergent lignin (ADL) fractions were determined with the procedure of Goering and Van Soest (1970). Digestion coefficients were calculated using the formula given by Schneider and Flatt (1975). Blood urea nitrogen (BUN) was determined according to the method of Crocker (1967), ruminal $\mathrm{NH}_{3}-\mathrm{N}$ using the micro kjeldahl method (AOAC, 1995) and VFA analyses by HPLC (Instruminalts by controller water model 600E; water model $484 \mathrm{UV}$ detector; column novapak $\mathrm{C}_{18}$; column size $4 \mathrm{~mm} \times 150 \mathrm{~mm}$; mobile phase $10 \mathrm{mM} \mathrm{H} \mathrm{H}_{2} \mathrm{SO}_{4}$ (pH 2.5), ETL Testing Laboratory, Inc., Cortland, New York, 13045, USA) according to Samuel et al. (1997). The amount of methane production was calculated from VFA composition according to Moss et al. (2000) as: $\mathrm{CH}_{4}$ production $=0.45$ (acetate) -0.275 (propionate) +0.4 (butyrate) . Plasma glucose, insulin, BHBA, and packed cell volume (PCV) were measured by using commercial kits (No. 640,
Sigma Chemical Co., St. Louis, USA). In urine samples, thawed urine samples were analyzed for Kjeldahl N (AOAC, 1995).

\section{Statistical analysis}

Statistical analyses were performed by using the GLM procedure (SAS Inst. Inc., Cary, NC). Data were analyzed by using the model $Y_{i j k}=\mu+M_{i}+A_{j}+P_{k}+\varepsilon_{i j k}$, where $Y_{i j k}=$ observation from animal $j$, receiving diet $i$, in period $k ; \mu=$ the overall of mean; $M_{i}=$ the mean effect of CGLY concentration $(i=1,2,3,4) ; A_{j}=$ the effect of animal $(j=1$, $2,3,4) ; P_{k}=$ the effect of period $(k=1,2,3,4)$; and $\varepsilon_{i j k}=$ the residual error. Treatment means were statistically compared by the new multiple range test of Duncan (Steel and Torrie, 1980) to identify differences between means. Significant differences were declared if $\mathrm{p}<0.05$. Orthogonal polynomial contrasts were used to estimate the effect of CGLY supplement level. 


\section{RESULTS AND DISCUSSION}

\section{Chemical composition of feeds}

The ingredients and chemical compositions of the treatments diets are presented in Table 1. The treatments diets contained $15.38 \%$ of CP, $6.41 \%$ of ash, $93.59 \%$ of OM and $19.62 \%$ of ADF on a DM basis. Dietary NFC content increased whereas NDF content decreased as proportion of CGLY in diets increased due to feeding less corn grain. Dietary $\mathrm{Ca}$ and $\mathrm{P}$ contents were similar among treatment diets.

\section{Intake and nutrient digestibility}

The effects of CGLY substitution of corn grain in the diets on feed intake and apparent digestibility of goats are presented in Table 2. Overall mean feed intakes for the four diets in terms of total DMI (\% BW and $\mathrm{g} / \mathrm{kg} \mathrm{BW}^{.75}$ ), OMI, CPI, NDFI, and ADFI were not significantly affected for all dietary treatments as compared between the experimental diets (5 to $20 \%$ of crude GLY) with the control diet. Likewise, nutrient (DM, OM, CP, EE, NDF, and ADF) digestibility was not affected ( $>0.05$ ) by inclusion of CGLY in the diets. The average DM intake was numerically higher in glycerin fed groups. Whereas, intake of ADF tended to be lower in the $20 \%$ of CGLY treated goats (p, Q $=0.08$ ) likely because of numerically reduced intakes. However, it remains unclear whether this was due to the dietary treatment. Our results are in agreement with a study by Mach et al. (2009) who fed diets containing different amounts of glycerin (up to $12 \%$ of DM) to Holstein bulls, and Gunn et al. (2010a) reported no changes in DMI when increasing concentrations of crude glycerin ( $0 \%$ to $20 \%$ of DM) were used to replace dry rolled corn in lamb diets.
Likewise, Avila-Stagno et al. (2013) used CGLY (up to 21\% of DM) for finishing lambs without adverse effect on nutrient intakes and digestibility. Similarly, a lack of effect of glycerol on total-tract digestibility of DM, OM, N, and NDF (Khalili et al., 1997) as well as in vitro (Rémond et al., 1993; Avila et al., 2011) and in vivo (Schröder and Südekum, 1999; Krueger et al., 2010) nutrient digestibility has been reported. Moreover, Wang et al. (2009) reported that increased DM digestibility with glycerol inclusion in cattle forage diets at concentrations of $0 \%$ to $3.3 \%$ of DM and Avila et al. (2011) reported that linear increases in IVDMD when glycerol was included at concentrations of $0 \%$ to $21 \%$ of DM as replacement of barley grain in $50 \%$ of barley grain- $50 \%$ of barley silage based feedlot cattle diets. In contrast, a decreased DM intake was reported when a diet containing $10 \%$ of glycerin as a corn replacement was fed to feedlot steers (Pyatt et al., 2007). Also, increasing glycerin to $4 \%, 8 \%, 12 \%$, and $16 \%$ of DM reduced DM intake in finishing heifers (Parsons et al., 2009). DM intakes particularly decreased when glycerin was fed to finishing lambs in high amounts up to $45 \%$ (Musselman et al., 2008; Gunn et al., 2010b). Indeed, substituting corn with high levels of glycerin was reported to adversely affect ruminal fermentation through reducing fiber digestion, acetate production, and bacterial populations (Abo El-nor et al., 2010).

Roger et al. (1992) demonstrated that introducing glycerol to the ruminal environment reduced cellulolytic activity of ruminal bacteria, and Paggi et al. (2004) also reported that digestibility of other substrates in the diet might be inhibited with the inclusion of glycerol in an in vitro environment. However, more recent digestibility data support results from the current study. Krehbiel (2008)

Table 2. Effects of $0 \%, 5 \%, 10 \%$, and $20 \%$ of dietary crude glycerin on feed intake and apparent digestibility of goats

\begin{tabular}{|c|c|c|c|c|c|c|c|c|}
\hline \multirow{2}{*}{ Item } & \multicolumn{4}{|c|}{ Dietary crude glycerin $(\%)$} & \multirow{2}{*}{ SEM $^{2}$} & \multicolumn{3}{|c|}{ Contrasts, $\mathrm{p}$-value $^{1}$} \\
\hline & 0 & 5 & 10 & 20 & & $\mathrm{~L}$ & $\mathrm{Q}$ & $\mathrm{C}$ \\
\hline \multicolumn{9}{|l|}{$\overline{\mathrm{DMI}}(\mathrm{kg} / \mathrm{d})$} \\
\hline Total DMI (kg/d) & 0.908 & 0.946 & 0.970 & 0.915 & 0.03 & 0.83 & 0.31 & 0.74 \\
\hline DMI (\% BW) & 2.82 & 3.12 & 3.23 & 2.89 & 0.14 & 0.78 & 0.22 & 0.82 \\
\hline DMI (g/kg W $\left.{ }^{0.75}\right)$ & 67.29 & 73.36 & 75.69 & 68.49 & 3.12 & 0.79 & 0.21 & 0.80 \\
\hline OMI (kg/d) & 0.850 & 0.888 & 0.915 & 0.859 & 0.03 & 0.77 & 0.27 & 0.70 \\
\hline CPI (kg/d) & 0.140 & 0.145 & 0.148 & 0.141 & 0.01 & 0.83 & 0.41 & 0.75 \\
\hline NDFI (kg/d) & 0.400 & 0.401 & 0.371 & 0.357 & 0.01 & 0.07 & 0.71 & 0.57 \\
\hline $\mathrm{ADFI}(\mathrm{kg} / \mathrm{d})$ & 0.176 & 0.189 & 0.194 & 0.174 & 0.01 & 0.99 & 0.08 & 0.67 \\
\hline \multicolumn{9}{|c|}{ Apparent digestibility (\%) } \\
\hline DM & 71.92 & 75.22 & 74.22 & 75.86 & 3.60 & 0.44 & 0.79 & 0.62 \\
\hline $\mathrm{OM}$ & 73.37 & 76.48 & 76.28 & 77.27 & 3.32 & 0.38 & 0.71 & 0.73 \\
\hline $\mathrm{CP}$ & 75.73 & 79.21 & 79.45 & 79.28 & 3.17 & 0.42 & 0.54 & 0.83 \\
\hline $\mathrm{EE}$ & 82.41 & 83.50 & 84.98 & 85.06 & 2.07 & 0.30 & 0.77 & 0.58 \\
\hline $\mathrm{NDF}$ & 61.30 & 61.06 & 54.89 & 53.67 & 4.95 & 0.15 & 0.91 & 0.57 \\
\hline $\mathrm{ADF}$ & 36.98 & 43.05 & 36.16 & 29.82 & 6.47 & 0.25 & 0.26 & 0.57 \\
\hline
\end{tabular}

\footnotetext{
${ }^{\mathrm{a}-\mathrm{c}}$ Means within rows followed with different superscript letters are statistically different $(\mathrm{p}<0.05)$.

${ }^{1}$ Linear (L), quadratic (Q), and cubic (C) effects of CGLY. ${ }^{2}$ SEM = Standard error of the mean $(n=4)$.
} 
reported that microorganisms adapted rapidly to glycerol feeding because elevated disappearance rates of glycerol were noted with increased days of glycerol feeding. Additionally, Hess et al. (2008) reported that crude glycerin could be added at $15 \%$ of DM to ruminant diets without negatively affecting to DM or fiber digestibility. These data, coupled with data from the current study, suggest that the ruminal environment, and concurrent decrease in DMI, may not be affected until crude glycerin concentrations exceed $20 \%$ of dietary DM. Further research, however, is needed to test this hypothesis and pinpoint the exact causes of decreased feedlot performance associated with elevated amounts $(>20 \%)$ of crude glycerin in the diet.

\section{Fermentation characteristics and methane production}

Ruminal parameters were measured for $\mathrm{pH}, \mathrm{NH}_{3}-\mathrm{N}$, and BUN. In addition, BUN was determined to investigate their relationship with ruminal $\mathrm{NH}_{3}-\mathrm{N}$ and protein utilization. The patterns of ruminal fermentation are given in Table 3. Ruminal $\mathrm{pH}$ and $\mathrm{NH}_{3}-\mathrm{N}$ were unchanged by dietary treatments in this study, indicating no specific effect of the inclusion of CGLY, except for $20 \%$ of CGLY, $\mathrm{NH}_{3}-\mathrm{N}$ was lower $(\mathrm{p}<0.05)$ than for the diets $10 \%$ of CGLY, while the difference between the diets $0 \%, 5 \%$, and $20 \%$ of CGLY were not significant. Ruminal $\mathrm{pH}$ in the present study was within the optimum range for cellulolytic bacteria activity (Russell and Wilson, 1996) and also digestion of protein (6.0 to 7.0). Concentration of ruminal $\mathrm{NH}_{3}-\mathrm{N}$ was higher than $5 \mathrm{mg} \%$, which is the optimal level of $\mathrm{NH}_{3}-\mathrm{N}$ for microbial protein synthesis in mixed culture in a close system (Satter and Slyter, 1974). Moreover, the ruminal ammonia concentrations in all animals were closer to optimal ruminal $\mathrm{NH}_{3}-\mathrm{N}$ (15 to $30 \mathrm{mg} \%$, Perdok and Leng, 1990) for improving microbial protein synthesis and digestibility and feed intake. In the study of Erdman et al.
(1986), maximum DM digestion of feeds of low and high degradability occurred at ruminal ammonia concentrations of 170 and $250 \mathrm{mg} / \mathrm{L}$, respectively. Likewise, BUN concentration were similar among treatments, except for $20 \%$ of CGLY, BUN was lower $(\mathrm{p}<0.05)$ than for the diets $5 \%$ of CGLY, while the difference between the diets $0 \%$, $10 \%$, and $20 \%$ of CGLY were not significant, ranging from 19.35 to $24.50 \mathrm{mg} / \mathrm{dL}$. It was close to the optimal level in normal goats which had been reported in the range of 11.2 to $27.7 \mathrm{mg} / \mathrm{dL}$ (Lloyd, 1982). The lack of effects of CGLY inclusion on $\mathrm{pH}$ and $\mathrm{NH}_{3}-\mathrm{N}$ are in accordance with previous reports in lambs (Abo El-nor et al., 2010) and beef cattle (Mach et al., 2009). Conversely, Wang et al. (2009) reported that supplementing steers with glycerol (200 or $300 \mathrm{~g} / \mathrm{d}$ ) had a tendency to decrease $\mathrm{pH}$ and $\mathrm{NH}_{3}-\mathrm{N}$ content $(\mathrm{p}=0.05$ and $\mathrm{p}=0.03$, respectively). The decrease in $\mathrm{NH}_{3}-\mathrm{N}$ in the ruminal of CGLY might be due to the reduction of proteolytic activity of ruminal microorganisms (Paggi et al., 1999) who found that adding CGLY reduced proteolytic activity by $20 \%$ when concentrations of CGLY in the medium.

The effect of the treatment diets on VFA profiles are presented in Table 3. No differences were found on mean total ruminal VFA concentration, and molar proportion of butyrate and other VFA (isobutyrate, isovalerate, valerate, and caproate) whereas molar proportion of acetate and propionate were affected $(\mathrm{p}<0.05)$ by CGLY level. The molar proportion of acetate linearly decreased $(p, L=0.05)$ whereas propionate was linearly increased $(\mathrm{p}, \mathrm{L}=0.01)$ with increasing CGLY supplementation. In consequence, the ratio of acetate to propionate was linearly reduced and was the lowest with the $20 \%$ of CGLY relative to the $0 \%$ of CGLY diet which was similar among other diets. In agreement with these results, previous studies (DeFrain et al., 2004; Trabue et al., 2007) had reported that animals

Table 3. Effects of $0 \%, 5 \%, 10 \%$, and $20 \%$ of dietary crude glycerin on ruminal fermentation and volatile fatty acid profiles in goats

\begin{tabular}{|c|c|c|c|c|c|c|c|c|}
\hline \multirow{2}{*}{ Item } & \multicolumn{4}{|c|}{ Dietary crude glycerin $(\%)$} & \multirow{2}{*}{$\mathrm{SEM}^{2}$} & \multicolumn{3}{|c|}{ Contrasts, $\mathrm{p}$-value ${ }^{1}$} \\
\hline & 0 & 5 & 10 & 20 & & $\mathrm{~L}$ & $\mathrm{Q}$ & $\mathrm{C}$ \\
\hline$\overline{\text { Ruminal } \mathrm{pH}}$ & 6.53 & 6.51 & 6.48 & 6.48 & 0.06 & 0.70 & 0.89 & 0.93 \\
\hline $\mathrm{NH}_{3}-\mathrm{N}(\mathrm{mg} / \mathrm{dL})$ & $21.27^{\mathrm{ab}}$ & $21.86^{\mathrm{a}}$ & $21.83^{\mathrm{a}}$ & $20.29^{\mathrm{b}}$ & 0.42 & 0.99 & 0.82 & 0.56 \\
\hline BUN (mg/dL) & $21.26^{\mathrm{ab}}$ & $24.50^{\mathrm{a}}$ & $20.47^{\mathrm{ab}}$ & $19.35^{\mathrm{b}}$ & 1.36 & 0.26 & 0.26 & 0.24 \\
\hline Total VFA $(\mathrm{mmol} / \mathrm{L})$ & 66.80 & 70.19 & 81.32 & 75.63 & 4.38 & 0.21 & 0.49 & 0.41 \\
\hline \multicolumn{9}{|c|}{ Proportion of individual VFA (\%) } \\
\hline Acetate $\left(\mathrm{C}_{2}\right)$ & 66.27 & 63.65 & 59.39 & 58.62 & 2.63 & 0.05 & 0.74 & 0.69 \\
\hline Propionate $\left(\mathrm{C}_{3}\right)$ & $19.11^{\mathrm{b}}$ & $21.30^{\mathrm{b}}$ & $24.85^{\mathrm{ab}}$ & $28.00^{\mathrm{a}}$ & 1.81 & 0.01 & 0.84 & 0.87 \\
\hline Butyrate $\left(\mathrm{C}_{4}\right)$ & 12.31 & 12.40 & 13.47 & 10.84 & 1.21 & 0.69 & 0.47 & 0.58 \\
\hline Other VFA ${ }^{3}$ & 2.30 & 2.64 & 2.25 & 2.82 & 0.49 & 0.43 & 0.69 & 0.52 \\
\hline $\mathrm{C}_{2}: \mathrm{C}_{3}$ ratio & $3.49^{\mathrm{a}}$ & $3.15^{\mathrm{ab}}$ & $2.78^{\mathrm{ab}}$ & $2.25^{\mathrm{b}}$ & 0.25 & 0.03 & 0.80 & 0.94 \\
\hline Methane $^{4}(\%)$ & $29.49^{\mathrm{a}}$ & $27.75^{\mathrm{ab}}$ & $25.28^{\mathrm{ab}}$ & $23.01^{\mathrm{b}}$ & 1.40 & 0.01 & 0.87 & 0.90 \\
\hline
\end{tabular}

${ }_{\mathrm{a}-\mathrm{c}}$ Means within rows followed with different superscript letters are statistically different $(\mathrm{p}<0.05)$.

${ }^{1}$ Linear (L), quadratic (Q), and cubic (C) effects of CGLY. ${ }^{2}$ SEM $=$ Standard error of the mean $(n=4)$.

${ }^{3}$ Sum of isobutyrate, isovalerate, valerate and caproate. ${ }^{4} \mathrm{CH}_{4}=(0.45 \times$ acetic acid $)-(0.275 \times$ propionic acid $)+(0.40 \times$ butyric acid $)($ Moss et al., 2000$)$. 
supplemented with glycerol had greater ruminal molar proportions of propionate with a decreased ratio of acetate to propionate than unsupplemented animals. It is likely that CGLY underwent ruminal fermentation to propionate and is similar to a fermentable carbohydrate source. Previous studies had showed that glycerol was mostly fermented into propionate (Garton et al., 1961; Bergner et al., 1995). Additionally, drenching cows with $1 \mathrm{~kg}$ of glycerol (Linke et al., 2004) or supplementing steers with glycerol (200 or $300 \mathrm{~g} / \mathrm{d}$; Wang et al., 2009) have been shown to increase ruminal propionate relative to control (no glycerol). The increase in propionate formation from the fermented glycerol used in this study may have offset any reduction in propionate. Moreover, the reduction in the molar proportion of acetate and acetate to propionate ratio was probably due to the reduction in NDF digestibility. Several studies reporting a reduction in NDF digestibility also reported reductions in acetate concentration and acetate to propionate ratio (Ribeiro et al., 2005; Castillejos et al., 2006; Abo El-nor et al., 2010). Likewise, $\mathrm{CH}_{4}$ production was linearly decreased $(\mathrm{p}, \mathrm{L}=0.01)$ with increasing CGLY supplementation. The change of $\mathrm{CH}_{4}$ concentration in the rumen is consistent with the reduced acetate: propionate when feeding CGLY. Similarly, Lee et al. (2011) reported a reduction of the A:P ratio, with an associated reduction in in vitro $\mathrm{CH}_{4}$ production after the supplementation of alfalfa hay and corn grain with glycerin, thus suggesting that although the fermentation of glycerin did not necessarily result in the formation of $\mathrm{a}_{2}$ sink, its ability to promote a shift in carbohydrate fermentation from the production of acetate to propionate might affect the overall electron balance in the rumen and reduce the availability of hydrogen for methane formation.

\section{Blood metabolites and insulin}

Serum insulin, glucose, BHBA, and PCV concentrations are presented in Table 4. Mean serum glucose, BHBA, and PCV concentrations were not affected $(p>0.05)$ by dietary treatments. It should be noted, however, that overall serum glucose concentration tended $(\mathrm{L}, \mathrm{p}=0.11)$ to be numerically greater than for goats fed CGLY inclusion in diets, when compared with goats not fed by CGLY, but all were within the normal range 50 to $75 \mathrm{mg} / \mathrm{dL}$ (2.78 to 4.16 $\mathrm{mmol} / \mathrm{L})$ (Kaneko, 1980). In agreement to the present results, Parker et al. (2007) reported greater blood glucose concentrations in animals supplemented with $642 \mathrm{~g}$ of pure glycerol $48 \mathrm{~h}$ before slaughtering than in unsupplemented animals, and Goff and Horst (2001) reported an increase in plasma glucose when administering glycerol via an esophageal pump. Similarly, Chung et al. (2007) reported that feeding glycerol to dairy cows increased circulatory glucose concentrations. In ruminants, glycerol can be rapidly converted to propionic acid and readily absorbed through the ruminal wall (Johns, 1953; Kijora et al., 1998). Therefore, the glycerol component can be converted to glucose by the liver and kidneys (Krebs and Lund, 1966) to provide energy for cellular metabolism. Glucose, as a source of energy, is necessary for production and reproduction performance (Radostits et al., 2000). Blood glucose level may serve as indicators for a goat's energy status. In the present experiment, these data indicate that goats consuming the diets with CGLY were in a normal energy status. This may be the possible reason for the lack of differences among treatments and there were no deleterious effects on feed intake or the metabolism of the goats. However, the variation in glucose concentration could be affected by many factors. Probably, the increase in blood glucose concentrations following glycerin supplementation depends on the physiological state of the animal and its energy balance (Mach et al., 2009) or disease conditions (Ford et al., 1990). Moreover, sampling is very important, as prior to morning feed, absorption of nutrients from the digestive tract was at minimum level (Hove and Halse, 1983). Linke et al. (2004) compared delivery methods of glycerol (feeding vs. drenching $800 \mathrm{~g}$ ) and found drenching to be more efficacious at increasing plasma glucose and insulin concentrations.

Overall circulating concentrations of serum insulin linearly increased $(\mathrm{p}, \mathrm{L}=0.002)$ with increasing the amount of CGLY supplementation. Circulating insulin concentrations usually correspond to changes in circulating glucose concentrations (Evans et al., 1975; Jenny and Polan, 1975). However, insulin secretion is a result of many factors and, in some cases, has been reported to have a low correlation with blood glucose concentrations (McAtee and Trenkle, 1971). Although insulin secretion responds to circulating glucose concentrations, a lag between increased concentrations of glucose and insulin is often reported

Table 4. Effects of $0 \%, 5 \%, 10 \%$, and $20 \%$ of dietary crude glycerin on blood metabolites and insulin in goats

\begin{tabular}{|c|c|c|c|c|c|c|c|c|}
\hline \multirow{2}{*}{ Item } & \multicolumn{4}{|c|}{ Dietary crude glycerin $(\%)$} & \multirow{2}{*}{ SEM $^{2}$} & \multicolumn{3}{|c|}{ Contrasts, $\mathrm{p}$-value $^{1}$} \\
\hline & 0 & 5 & 10 & 20 & & $\mathrm{~L}$ & Q & $\mathrm{C}$ \\
\hline$\overline{\text { Glucose }(\mathrm{mg} / \mathrm{dL})}$ & 67.36 & 71.59 & 71.95 & 75.73 & 2.59 & 0.11 & 0.94 & 0.63 \\
\hline Insulin $(\mu \mathrm{U} / \mathrm{mL})$ & $1.85^{\mathrm{b}}$ & $2.94^{\mathrm{ab}}$ & $7.60^{\mathrm{a}}$ & $7.44^{\mathrm{a}}$ & 1.29 & 0.002 & 0.62 & 0.16 \\
\hline $\mathrm{BHBA}(\mathrm{mg} / \mathrm{dL})$ & 4.82 & 5.75 & 4.66 & 4.62 & 0.33 & 0.30 & 0.19 & 0.07 \\
\hline $\mathrm{PCV}(\%)$ & 31.25 & 31.12 & 29.12 & 31.25 & 1.50 & 0.78 & 0.49 & 0.42 \\
\hline
\end{tabular}

${ }^{\mathrm{a}-\mathrm{c}}$ Means within rows followed with different superscript letters are statistically different $(\mathrm{p}<0.05)$.

${ }^{1}$ Linear (L), quadratic (Q), and cubic (C) effects of CGLY. ${ }^{2}$ SEM = Standard error of the mean $(n=4)$. 
(Lake et al., 2006), whereas Gunn et al. (2010b) reported that insulin concentrations also increased linearly relative to time of sampling around feeding $(\mathrm{p}<0.001)$. Peak insulin concentrations in the present study correspond with greater concentrations of circulating glucose.

The effects of CGLY on BHBA and PCV concentrations were similar $(p>0.05)$ among treatments with ranging of 4.62 to $5.75 \mathrm{mg} / \mathrm{dL}$ and $29.12 \%$ to $31.25 \%$, respectively. PCV was close to the optimal level in normal goats which had been reported in the range of 22 to $38 \%$ (Lloyd, 1982). This lack of response is likely due to goats consuming the diets with CGLY were in a normal or positive energy status. These data suggest a shift to reduce fatty acid oxidation to ketones or to increase utilization of ketones by extrahepatic tissues when glycerol is fed. Similarly, Mulliniks et al. (2008) reported a decrease in serum ketone concentrations of postpartum range cows fed a glucogenic precursor in the form of propionate salt, and other glucogenic agents such as propylene glycol or glycerol. Conversely, Linke et al. (2004) found that both feeding and drenching $800 \mathrm{~g}$ of glycerol increased the molar percentage of ruminal butyrate and plasma BHBA. Because dietary short-chain fatty acids, mainly butyrate, are primary contributors to alimentary ketogenesis (Bergman, 1971), perhaps the ruminal fermentation of glycerol to butyrate increased plasma BHBA and decreased concentrations of glucose in plasma.

\section{Nitrogen utilization}

Whole body $\mathrm{N}$ data are presented in Table 5 . Total $\mathrm{N}$ intake and total $\mathrm{N}$ excretion in terms of fecal and urinary $\mathrm{N}$ were similar $(p>0.05)$ between control diet and CGLY inclusion in diets. This pattern of fecal and urine excretion is indicative of the extremely high $\mathrm{N}$ intake for goats fed diets containing of CGLY. This could be explained by the fact that excess ruminal $\mathrm{NH}_{3}-\mathrm{N}$ is absorbed and excreted in the urine in the form of urea (Nolan, 1993). Additionally, Cronje (1992) found that inadequate energy reduced the percentage of $\mathrm{N}$ retention in goats fed adequate levels of protein and that $\mathrm{N}$ recycling increased as the supply of energy increased.

Likewise, the amount of $\mathrm{N}$ absorption and retention were similar among treatments. It is now well established that nitrogen retention depends on the intake of nitrogen, amount of fermentable carbohydrate of the diet (Sarwar et al., 2003). In this regard, however, the positive $\mathrm{N}$ balance observed in this study indicated the positive influence of different CGLY replacement of corn grain in the diets with TMR based feeding of goats. Although the differences in the quantity and routes of $\mathrm{N}$ excretion with consequent influences on $\mathrm{N}$ retention could reflect treatment feed differences in $\mathrm{N}$ metabolism, in which $\mathrm{N}$ retention was considered as the most common index of the protein nutrition status of ruminants (Owens and Zinn, 1988). Data from the present study indicated that up to $20 \%$ of CGLY could be fed in a TMR without negatively affecting feed intake, digestibility, nitrogen balance, and animal performance.

\section{CONCLUSIONS}

CGLY (87.61\% glycerol) was a good alternative energy source to substitute for corn gain in the diets. Based on the experimental data, substituting corn grain with CGLY up to $20 \%$ of DM in the diets of goats had no effect on feed intake, digestibility, ruminal fermentation patterns, blood metabolites, and nitrogen utilization, and it could be effectively used as an alternative energy source to substitute for cereals in the diets. Thus, in the case of a competitive price, CGLY may be effectively used as a partial energy source in the diets of goats. However, further research and long-term studies should be conducted to validate the effects of supplementing of CGLY in finishing goats and to determine the optimal feeding rates in dairy goats.

Table 5. Effects of $0 \%, 5 \%, 10 \%$, and $20 \%$ of dietary crude glycerin on nitrogen utilization of goats

\begin{tabular}{|c|c|c|c|c|c|c|c|c|}
\hline \multirow{2}{*}{ Item } & \multicolumn{4}{|c|}{ Dietary crude glycerin $(\%)$} & \multirow{2}{*}{$\mathrm{SEM}^{2}$} & \multicolumn{3}{|c|}{ Contrasts, $\mathrm{p}$-value $^{1}$} \\
\hline & 0 & 5 & 10 & 20 & & $\mathrm{~L}$ & Q & $\mathrm{C}$ \\
\hline \multicolumn{9}{|l|}{$\mathrm{N}$ balance $(\mathrm{g} / \mathrm{d})$} \\
\hline Total $\mathrm{N}$ intake & 22.45 & 23.20 & 23.77 & 22.62 & 0.84 & 0.82 & 0.39 & 0.75 \\
\hline \multicolumn{9}{|l|}{$\mathrm{N}$ excretion $(\mathrm{g} / \mathrm{d})$} \\
\hline Fecal N & 5.48 & 4.89 & 4.82 & 4.70 & 0.76 & 0.49 & 0.76 & 0.86 \\
\hline Urinary $\mathrm{N}$ & 3.28 & 6.04 & 5.76 & 5.67 & 1.54 & 0.44 & 0.69 & 0.24 \\
\hline Total $\mathrm{N}$ excretion & 8.76 & 10.93 & 10.58 & 10.37 & 1.95 & 0.65 & 0.59 & 0.78 \\
\hline Absorbed N & 16.96 & 18.31 & 18.95 & 17.92 & 1.10 & 0.46 & 0.27 & 0.84 \\
\hline Retained N & 13.79 & 12.27 & 13.19 & 12.24 & 1.96 & 0.71 & 0.89 & 0.66 \\
\hline \multicolumn{9}{|c|}{$\mathrm{N}$ output (\% of $\mathrm{N}$ intake) } \\
\hline Absorbed & 75.67 & 79.22 & 79.45 & 79.28 & 3.17 & 0.41 & 0.54 & 0.82 \\
\hline Retained & 61.57 & 53.38 & 55.31 & 53.33 & 7.78 & 0.58 & 0.73 & 0.73 \\
\hline
\end{tabular}

\footnotetext{
${ }^{a-c}$ Means within rows followed with different superscript letters are statistically different $(\mathrm{p}<0.05)$.
}

${ }^{1}$ Linear (L), quadratic (Q), and cubic (C) effects of CGLY. ${ }^{2}$ SEM $=$ Standard error of the mean $(n=4)$. 


\section{ACKNOWLEDGEMENTS}

The authors would like to express their most sincere gratitude and appreciation to the Department of Animal Science, Faculty of Natural Resources, Prince of Songkla University for financial support of this research (Project no. NAT550288S).

Supported in part by a grant from Prince of Songkla University.

\section{REFERENCES}

Abo El-Nor, S., A. A. AbuGhazaleh, R. B. Potu, D. Hastings, and M. S. A. Khattab. 2010. Effects of different levels of glycerol on ruminal fermentation and bacteria. Anim. Feed Sci. Technol. 162:99-105.

AOAC. 1995. Official methods of analysis. 16th ed. Assoc. Off. Anal. Chem., Arlington, VA.

Avila, J. S., A. V. Chaves, L. M. Hernandez-Calva, K. A. Beauchemin, S. M. McGinn, Y. Wang, O. M. Harstad, and T. A. McAllister. 2011. Effects of replacing barley grain in feedlot diets with increasing levels of glycerol on in vitro fermentation and methane production. Anim. Feed Sci. Technol. 166167:265-268.

Avila-Stagno, J., A. V. Chaves, M. L. He, O. M. Harstad, K. A. Beauchemin, S. M. McGinn, and T. A. McAllister. 2013. Effects of increasing concentrations of glycerol in concentrate diets on nutrient digestibility, methane emissions, growth, fatty acid profiles, and carcass traits of lambs. J. Anim. Sci. 91:829837.

Bergman, E. N. 1971. Hyperketonemia-ketogenesis and ketone body metabolism. J. Dairy Sci. 54:936-948.

Bergner, H., C. Kijora, Z. Ceresnakova, and J. Szakacs. 1995. In vitro studies on glycerol transformation by ruminal microorganisms. Arch. Tierenahr. 48:245-256.

Carvalho, E. R., N. S. Schmelz-Roberts, H. M. White, P. H. Doane, and S. S. Donkin. 2011. Replacing corn with glycerol in diets for transition dairy cows. J. Dairy Sci. 94:908-916.

Castillejos, L., S. Calsamiglia, and A. Ferret. 2006. Effect of essential oils active compounds on ruminal microbial fermentation and nutrient flow in in vitro systems. J. Dairy Sci. 89:2649-2658.

Chung, Y. H., D. E. Rico, C. M. Martinez, T. W. Cassidy, N. Noirot, A. Ames, and G. A. Varga. 2007. Effects of feeding dry glycerin to early postpartum Holstein dairy cows on lactational performance and metabolic profiles. J. Dairy Sci. 90:56825691.

Crocker, C. L. 1967. Rapid determination of urea-nitrogen in serum or plasma without deproteinization. Am. J. Med. Technol. 33:361-365.

Cronje, P. B. 1992. Differences in nitrogen and urea metabolism between goats bred for fibre production (Angora goat) or meat production (Boer goat). S. Afr. J. Anim. Sci. 22:143-148.

Dasari, M. A., P. P. Kiatsimkul, W. R. Sutterlin, and G. J. Suppes. 2005. Low-pressure hydrogenolysis of glycerol to propylene glycol. Appl. Catal. A: Gen. 281:225-231.

DeFrain, J. M., A. R. Hippen, K. F. Kalscheur, and P. W. Jardon.
2004. Feeding glycerol to transition dairy cows: Effects on blood metabolites and lactation performance. J. Dairy Sci. 87:4195-4206.

Donkin, S. S., S. L. Koser, H. M. White, P. H. Doane, and M. J. Cecava. 2009. Feeding value of glycerol as a replacement for corn grain in rations fed to lactating dairy cows. J. Dairy Sci. 92:5111-5119.

Erdman, R. A., G. H. Proctor, and J. H. Vandersall. 1986. Effect of ruminal ammonia concentration on in situ rate and extent of digestion of feedstuffs. J. Dairy Sci. 69:2312-2320.

Evans, E., J. G. Buchanan-Smith, and G. K. Macleod. 1975. Postprandial patterns of plasma glucose, insulin and volatile fatty acids in ruminants fed low- and high-roughage diets. J. Anim. Sci. 41:1474-1479.

FDA. 2007. Code of federal regulations. Title 21, Volume 6. 21CFR582.1320. http://www.accessdata.fda.gov/scripts/cdrh/ cfdocs/cfcfr/CFRSearch.cfm?fr=582.1320. Accessed on 2 March, 2013.

Ford, E. J., J. Evans, and I. Robinson. 1990. Cortisol in pregnancy toxemia of sheep. Br. Vet. J. 146:539-542.

Garton, G. A., A. K. Lough, and E. Vioque. 1961. Glyceride hydrolysis and glycerol fermentation by sheep ruminal contents. J. Gen. Microbiol. 25:215-225.

Goering, H. K. and P. J. Van Soest. 1970. Forage Fiber Analysis (apparatus, reagents, procedures, and some applications). Agriculture Handbook. No. 370, USDA-ARS, Washington, DC, p. 20.

Goff, J. P. and R. L. Horst. 2001. Oral glycerol as an aid in the treatment of ketosis/fatty liver complex. J. Dairy Sci. 84(Suppl. 1):153. (Abstr.)

Gunn, P. J., M. K. Neary, R. P. Lemenager, and S. L. Lake. 2010a. Effects of crude glycerin on performance and carcass characteristics of finishing wether lambs. J. Anim. Sci. 88:1771-1776.

Gunn, P. J., A. F. Schultz, M. L. Van Emon, M. K. Neary, R. P. Lemenager, C. P. Rusk, and S. L. Lake. 2010b. Effects of elevated crude glycerin concentrations on feedlot performance, carcass characteristics, and serum metabolite and hormone concentrations in finishing ewe and wether lambs. Prof. Anim. Sci. 26:298-306.

Hess, B. W., S. L. Lake, and S. A. Gunter. 2008. Using glycerin as a supplement for forage-fed ruminants. J. Anim. Sci. 86(ESuppl. 2):392. (Abstr.).

Hove, K. and K. Halse. 1983. Energy metabolism in ruminants with special reference on ketosis and fertility. Proc. 5th Int. onf. Prod. Dis. Farm Anim. Uppsata, Sweden, pp. 115-123.

Hungate, R. E. 1966. The ruminal and its microbe. Acadimic Press, New York. NY. p. 533.

Jenny, B. F. and C. E. Polan. 1975. Postprandial blood glucose and insulin in cows fed high grain. J. Dairy Sci. 58:512-514.

Johns, A. 1953. Fermentation of glycerol in the ruminal of sheep. New Zealand J. Sci. Technol. 35:262-269.

Kaneko, J. J. 1980. Appendixes. In: Clinical Biochemistry of Domestic Animals, 3rd ed. (Ed. J. J. Kaneko). New York, Academic Press.

Khalili, H., T. Varvikko, V. Toivonen, K. Hissa, and M. Suvitie. 1997. The effects of added glycerol or unprotected free fatty acids or a combination of the two on silage intake, milk 
production, ruminal fermentation and diet digestibility in cows given grass silage based diets. Agric. Food Sci. Finl. 6:349-362.

Kijora, C., H. Bergner, K. P. Gotz, J. Bartelt, J. Szakacs, and A. Sommer. 1998. Research note: Investigation on the metabolism of glycerol in the rumen of bulls. Arch. Tierernahr. 51:341-348.

Krebs, H. A. and P. Lund. 1966. Formation of glucose from hexoses, pentoses, polyols and related substances in kidney cortex. Biochem. J. 98:210-214.

Krehbiel, C. R. 2008. Ruminal and physiological metabolism of glycerin. J. Anim. Sci. 86(E-Suppl. 2):392. (Abstr.).

Krueger, N. A., R. C. Anderson, L. O. Tedeschi, T. R. Callaway, T. S. Edrington, and D. J. Nisbet. 2010. Evaluation of feeding glycerol on free-fatty acid production and fermentation kinetics of mixed ruminal microbes in vitro. Bioresour. Technol. 101:8469-8472.

Lake, S. L., E. J. Scholljegerdes, D. M. Hallford, G. E. Moss, D. C. Rule, and B. W. Hess. 2006. Effects of body condition score at parturition and postpartum supplemental fat on metabolite and hormone concentrations of beef cows and their suckling calves. J. Anim. Sci. 84:1038-1047.

Lammers, P. J., B. J. Kerr, M. S. Honeyman, W. A. Dozier, T. E. Weber, T. E. Kidd, and K. Bregendahl. 2008a. Nitrogen corrected apparent metabolism energy value of crude glycerol for layer hens. Poult. Sci. 87:104-107.

Lammers, P. J., B. J. Kerr, T. E. Weber, W. A. Dozier, III, M. T. Kidd, K. Bregendahl, and M. S. Honeyman. 2008b. Digestible and metabolizable energy of crude glycerol for growing pigs. J. Anim. Sci. 86:602-608.

Lee, S. Y., S. M. Lee, Y. B. Cho, D. K. Kam, S. C. Lee, C. H. Kim, and S. Seo. 2011. Glycerol as a feed supplement for ruminants: In vitro fermentation characteristics and methane production. Anim. Feed Sci. Technol. 166-167:269-274.

Linke, P. L., J. M. DeFrain, A. R. Hippen, and P. W. Jardon. 2004. Ruminal and plasma responses in dairy cows to drenching or feeding glycerol. J. Dairy Sci. 87(Suppl.):343(Abstr.).

Lloyd, S. 1982. Blood characteristics and the nutrition of ruminants. Br. Vet. J. 138:70-85.

Mach, N., A. Bach, and M. Devant. 2009. Effects of crude glycerin supplementation on performance and meat quality of Holstein bulls fed high-concentrate diets. J. Anim. Sci. 87:632-638.

McAtee, J. W. and A. Trenkle. 1971. Metabolic regulation of plasma insulin levels in cattle. J. Anim. Sci. 33:438-442.

Mertens, D. R. 1997. Creating a system for meeting the fiber requirements of dairy cows. J. Dairy Sci. 80:1463-1481.

Min, Y. N., F. Yan, F. Z. Liu, C. Coto, and P. W. Waldroup. 2010. Glycerin a new energy source for poultry. Int. J. Poult. Sci. 9:1-4.

Mulliniks, J. T., M. E. Kemp, S. I. Valverde-Saenz, M. B. Horvath, S. H. Cox, A. Cibils, C. A. Loest, and M. K. Petersen. 2008. Impact of supplemented glucogenic precursors on nutrient partitioning in young postpartum range cows. Page 391 in Proc. West. Sect. Am. Soc. Anim. Sci., vol. 59, Laramie, WY.

Musselman, A. F., M. L. Van Emon, P. J. Gunn, C. P. Rusk, M. K. Neary, R. P. Lemenager, and S. L. Lake. 2008. Effects of crude glycerin on feedlot performance and carcass characteristics of market lambs. Am. Soc. Anim. Sci. West. Sect. Proc. 59:353355.
Nolan, J. V. 1993. Nitrogen kinetics. In: Quantitative Aspecta of Ruminant Digestion and Metabolism (Ed. R. C. Gutteridge and H. M. Shelton). CAB International, Willingford, UK. pp. 123143.

NRC. 1981. Nutrient requirements of goats: angora, dairy and meat goats in temperate and tropical countries. National Academy Press, Washington, DC, USA.

Owens, F. N. and R. Zinn. 1988. Protein metabolism of ruminant animals. In: The Ruminant Animal Digestive Physiology and Nutrition Church, DC, editor Waveland Press Inc., Prospect Hights, IL, USA.

Paggi, R. A., J. P. Fay, and C. Faverin. 2004. In vitro ruminal digestibility of oat hay and cellulolytic activity in the presence of increasing concentrations of short-chain acids and glycerol. J. Agric. Sci. 142:89-96.

Paggi, R. A., J. P. Fay, and H. M. Fernandez. 1999. Effect of shortchain acids and glycerol on the proteolytic activity of ruminal fluid. Anim. Feed Sci. Technol. 78:341-347.

Parker, A. J., G. P. Dobson and L. A. Fitzpartrick. 2007. Physiological and metabolic effects of prophylactic treatment with the osmolytes glycerol and betaine on Bos indicus steers during long duration transportation. J. Anim. Sci. 85:29162923.

Parsons, G. L., M. K. Shelor, and J. S. Drouillard. 2009. Performance and carcass traits of finishing heifers fed crude glycerin. J. Anim. Sci. 87:653-657.

Perdok, H. B. and R. A. Leng. 1990. Effect of supplementation with protein meal on the growth of cattle given a basal diet of untreated or ammoniated rice straw. Asian-Aus. J. Anim. Sci. 3:269-279.

Pyatt, A., P. H. Doane, and M. J. Cecava. 2007. Effect of crude glycerin in finishing cattle diets. J. Anim. Sci. 85(Suppl. 1):530 (Abstr.).

Radostits, O. M., C. C. Gay, D. C. Blood, and K. W. Hinchcliff. 2000. Veterinary medicine, 9th ed. Harcourt Publishers Ltd., London. pp. 1417-1420.

Rémond, B., E. Souday, and J. P. Jouany. 1993. In vitro and in vivo fermentation of glycerol by ruminal microbes. Anim. Feed Sci. Technol. 41:121-132.

Ribeiro, C. V. D. M., S. K. R. Karnati, and M. L. Eastridge. 2005. Biohydrogenation of fatty acids and digestibility of fresh alfalfa or alfalfa hay plus sucrose in continuous culture. J. Dairy Sci. 88:4007-4017.

Roger, V., G. Fonty, C. Andre, and P. Gouet. 1992. Effects of glycerol on the growth, adhesion, and cellulolytic activity of ruminal cellulolytic bacteria and anaerobic fungi. Curr. Microbiol. 25:197-201.

Russell, J. B. and D. B. Wilson. 1996. Why are ruminal cellulolytic bacteria unable to digest cellulose at low $\mathrm{pH}$ ? J. Dairy Sci. 79:1503-1509.

Samuel, M., S. Sagathewan, J. Thomas, and G. Mathen. 1997. An HPLC method for estimation of volatile fatty acids of ruminal fluid. Indian J. Anim. Sci. 67:805-807.

Sarwar, M., M. Ajmal Khan, and Mahr-un-Nisa. 2003. Nitrogen retention and chemical composition of urea treated wheat straw ensiled with organic acids or fermentable carbohydrate. Asian-Aust. J. Anim. Sci. 16:1583-1592.

Satter, L. D. and L. L. Slyter. 1974. Effect of ammonia 
concentration on ruminal microbial protein production in vitro. Br. J. Nutr. 32:199-208.

Schieck, S. J., B. J. Kerr, S. K. Baidoo, G. C. Shurson, and L. J. Johnston. 2010. Use of crude glycerol, a biodiesel coproduct, in diets for lactating sows. J. Anim. Sci. 88:2648-2656.

Schnieder, B. H. and W. P. Flatt. 1975. The evaluation of feed through digestibility experiment athens: The Univ. of Georgia Press. Georgia, USA.

Schröder, A. and K. H. Südekum. 1999. Glycerol as a by-product of biodiesel production in diets for ruminants. In New Horizons for an Old Crop. Proc. 10th Int. Rapeseed Congr., Canberra, Australia, September 26-29, 1999, Paper No. 241. N. Wratten and P. A. Salisbury, ed.
Steel, R. G. D. and J. H. Torrie. 1980. Principles and procedures of statistics: a biometrical approach. 2nd ed. McGraw-Hill Book Co., New York, NY.

Thompson, J. C. and B. B. He. 2006. Characterization of crude glycerin from biodiesel production from multiple feedstocks. Appl. Eng. Agric. 22:261-265.

Trabue, S., K. Scoggin, S. Tjandrakusuma, M. A. Rasmussen, and P. J. Reilly. 2007. Ruminal fermentation of propylene glycol and glycerol. J. Agric. Food. Chem. 55:7043-7051.

Wang, C., Q. Liu, W. J. Huo, W. Z. Yang, K. H. Dong, Y. X. Huang, and G. Guo. 2009. Effects of glycerol on ruminal fermentation, urinary excretion of purine derivatives and feed digestibility in steers. Livest. Sci. 121:15-20. 